\title{
Proceedings of the Local Branches
}

"All papers presented to the Association and its branches shall become the property of the Association, with the understanding that they are not to be published in any other publication than those of the Association, except by consent of the Committee on Publication."-By-Laws, Chapter X, Art. III.

Reports of the meetings of the Local Branches should be mailed to the Editor on the day following the meeting, if possible. Minutes should be typewritten, with wide spaces between the lines. Care should be taken to give proper names correctly, and manuscript should be signed by $t^{\text {he reporter. }}$

\section{NEW YORK.}

The December 1918 meeting of the New York Branch of the American Pharmaceutical Association was called to order by President J. L. Turner in the Lecture Hall of the New York College of Pharmacy Building on Monday, the gth; at 8.30 o'clock.

Thirty-five members were present.

The minutes of the previous meeting were read and approved.

\section{REPORT OF THE OFFICERS.}

Treasurer Horstmann sent word that he could not be present, but would mail the report.

Member of the Council.-Jeannot Hostmann had no report.

Membership Committee.-An application was received from Max Soskin, 439 Brook Ave,, New York City.

Fraternal Relations.--Chairman Leon I,ascoff had no report to bring in.

Audit Committee.-Chairman Jacob Diner reported that a number of bills had been passed and paid.

Legislation and Education.-Chairman Robert Lehman brought in a lengthy report, which was ordered accepted with the thanks of the Branch.

Under regular procedure the following nominating committee was appointed: Drs. Mayer, Anderson and Arny.

SCIENTIFIC SECTION.

Dr. Geo. C. Diekman, of the Committee on
Progress of Pharmacy, brought in a lengthy report and abstracts on the following:

Colormetric test of brucine.

Assay of opium.

Examination of Oil of Pennyroyal.

Identity test for guaiacol.

Method for rapid destruction of organic matter.

Power of vegetable decolorizing.

Exp. and action of magnesium salts on growth of wheat.

Valuation of balsam of tolu.

Considerable discussion followed the reading of this report, which was ordered accepted with the thanks of the Branch.

Dr. W. C. Anderson discussed the work of the Kings County Pharmaceutical Association.

Dr. Jacob Diner, Mr. Jacob Weil and Dr. Leon Lascoff reported that they wished to go on record that the Manhattan County Pharmaceutical Association would willingly join the American Pharmaceutical Association.

Dr. Joseph L. Mayer read a memorial in honor of Dr. F. E. Niece. It was moved, seconded and carried that a page in the minutes be set aside for these resolutions and that a copy be sent to the family of the deceased.

Under regular procedure the meeting was declared adjourned.

Hugo H. SchaEfer, Secretary.

\section{COMMITTEE RePORTS}

\section{SOLDIER AND SAILOR PHARMACISTS.}

Work of The A. Ph. A. Advisory Commitree.*

The A. Ph. A. Advisory Committee for Soldier and Sailor Pharmacists is meeting with a hearty response from the Retail Drug Trade of the country. The reports of the Committee

* The Committee held a meeting in Cincinnati December 27, and for this reason this letter is not printed in full, it being expected that the report of the meeting will more explicitly include the statements omitted. 
show that on December I 4 th there had been listed with it positions for 231 disabled pharmacists, in addition to 404 openings for clerkships to men who are not disabled. Many of the positions offered indicate exceptional opportunities for the returning men. Up to December I 4 th there were listed 565 drug stores, which are for sale to the returning meri, in many cases under very advantageous conditions. Partnership openings are offered by 157 druggists, who have grown old in the business and would be glad to be relieved of a part of their work and responsibilities. In the case of many of these partnership openings, a returning Soldier or Sailor Pharmacist will need only to have ability and good reputation. The offer for positions and openings come from every State in the country, and with very few exceptions, from the smaller cities and towns. In the larger cities of the country, the Committee hopes to arrange for coöperation through Local Associations, and is even now assured that the opportunities in the larger cities will be very great. The work of the Committee has only just commenced, and the early returns prove that it will be able to accomplish a great deal. The data gathered up to this time make plain that good drug clerks are in great demand in every section of the country, and the men who will first return from the Service will have no difficulty in finding positions, but it is also found that many places made vacant by those entering the Service have been satisfactorily filled, and many women have found employment in drug stores who are likely to retain their positions. The real problem of the Committee in rendering effective service will come when the last half of the men return. It is anticipated also, that many drug clerks returning from the Service, who have no strong home ties, will be disposed to look for places in the larger cities, and an effort will be made to induce distribution throughout the country.

The Committee is receiving a great number of requests for assistance in securing the early return of drug clerks for positions which are held open. This is not thought to be a part of the Committee's work; such endeavor would be involved with great difficulty, and would hardly find the approval of the authorities. The present plan of the Army seems to be to discharge men as much as possible in groups, and not to attempt to single out individuals. In the Navy, by far the larger part of the pharmacists seem to have been placed in the Hospital Corps, and the Bureau of Medicine, of the Navy Department, advises that there is at present greater need for these men than there has been at any time during the War, and it will not be practicable to release them for several months.

The Committee confidently looks for the continued hearty coöperation of the druggists at home, and either by direct correspondence or through work of Local Committees means to secure and list every opening in the country. One of its difficult problems will be to reach all of the Pharmacists who are now in the Service and who are more or less distributed over all parts of the globe. It is realized that the greatest success of the Committee's work will depend upon reaching the men while they are still in the Service, so that they can be informed and make their plans very largely before they return to civil life. Unfortunately, neither the Army nor the Navy seem to have made arrangements for conveying information of interest to separate classes, and lack of facilities in this respect is apt to greatly hinder the agencies at home which would be helpful in the readjustment to civil life. The Committee is determined to find a way for reaching directly every Pharmacist who continues in the Service beyond an early time, but it realizes that with proper coöperation from the Authorities this part of its work would be greatly aided. Quite a number of small contributions have reached the Committee, all of which are listed by Treasuret H. M. Whelpley, and duly appreciated. It may be stated, however, at this time, that the successful work of the Committee will very greatly, if not entirely, depend upon having ample funds. The work cannot be done properly without having sufficient clerical and office help. It must be in mind that correspondence with possibly twenty thousand persons will have to be systematically handled, and many publications will need to be made. The Drug Trade of the country, which has so readily responded to the Red Cross, Y. M. C. A., K. of C., and War Chest Appeals, now has an opportunity to show its willing generosity to those in whom it is more directly concerned. Without ample funds the work of the Committee cannot be successful. Remittances should be made payable to H. M. Whelpley, Treasurer, and can be mailed to him at No. 2342 Albion Place, St. Louis, Missouri, or to the Chairman, Frank H. Freericks, at No. roos Mercantile Library Bldg., Cincinnati, Ohio. 